\title{
A COMPARATIVE ANALYSIS OF THE EFFECT OF TEMPERATURE ON BAND-GAP ENERGY OF GALLIUM NITRIDE AND ITS STABILITY BEYOND ROOM TEMPERATURE USING BOSE-EINSTEIN MODEL AND VARSHNI'S MODEL
}

\author{
Md Abdullah Al Humayun ${ }^{1,2}$, AHM Zahirul Alam ${ }^{1 *}$, Sheroz Khan ${ }^{1}$, \\ MoHamed FAReQ Abdul MALEK ${ }^{3}$ AND MoHd Abdur RASHID ${ }^{4}$ \\ ${ }^{1}$ Department of Electrical and Computer Engineering, \\ International Islamic University Malaysia, Jalan Gombak, \\ 53100 Kuala Lumpur, Malaysia. \\ ${ }^{2}$ Department of Electrical and Electronic Engineering, \\ Green University of Bangladesh, Dhaka-1207, Bangladesh \\ ${ }^{3}$ Faculty of Engineering and Information Sciences, \\ University of Wollongong in Dubai, Dubai, United Arab Emirates. \\ ${ }^{4}$ Department of Electrical and Electronic Engineering, \\ Noakhali Science \& Technology University, Noakhali 3814, Bangladesh. \\ *Corresponding author: zahirulalam@iium.edu.my \\ (Received: 28 th July 2016; Accepted: 31 $1^{\text {st }}$ May 2017; Published on-line: $1^{\text {st }}$ Dec. 2017)
}

\begin{abstract}
High temperature stability of the band-gap energy of the active layer material of a semiconductor device is one of the major challenges in the field of semiconductor optoelectronic device design. It is essential to ensure the stability in different band-gap energy-dependent characteristics of the semiconductor material used to fabricate these devices either directly or indirectly. Different models have been widely used to analyze the band-gap energy-dependent characteristics at different temperatures. The most commonly used methods to analyze the temperature dependence of band-gap energy of semiconductor materials are: the Passler model, the Bose-Einstein model, and Varshni's model. This paper is going to report the limitation of the Bose-Einstein model through a comparative analysis between the Bose-Einstein model and Varshni's model. The numerical analysis is carried out considering GaN, as it is one of the most widely used semiconductor materials all over the world. From the numerical results it is ascertained that below the temperature of $95 \mathrm{~K}$ both the models show almost same characteristics. However, beyond $95 \mathrm{~K}$ Varshni's model shows weaker temperature dependence than that of the Bose-Einstein model. Varshni's model shows that the bandgap energy of $\mathrm{GaN}$ at $300 \mathrm{~K}$ is found to be $3.43 \mathrm{eV}$, which establishes a good agreement with the theoretically calculated band-gap energy of $\mathrm{GaN}$ for operation at room temperature.
\end{abstract}

ABSTRAK: Kestabilan bahan peranti semikonduktor pada suhu tinggi di lapisan aktif jurang tenaga (band-gap) adalah salah satu cabaran penting dalam bidang reka bentuk peranti optoelektronik semikonduktor. Faktor ini bergantung kepada bahan semikonduktor yang digunakan untuk proses fabrikasi peranti elektronik ini samada secara langsung atau tidak langsung, bagi memastikan kestabilan dalam pelbagai jurang lapisan tenaga. Model yang berbeza telah digunakan secara meluas untuk mengkaji kebergantungan ciri jurang lapisan tenaga bahan semikonduktor pada suhu yang berbeza. Kaedah yang paling biasa digunakan untuk menganalisa kebergantungan jurang lapisan 
tenaga bahan semikonduktor pada suhu adalah: model Passler, model Bose-Einstein dan model Varshni. Sementara itu pada suhu melebihi 95 K, model Varshni menunjukkan kebergantungan pada suhu adalah lemah berbanding model Bose-Einstein. Model Varshni menunjukkan bahawa jurang tenaga bagi GaN pada suhu $300 \mathrm{~K}$ adalah $3.43 \mathrm{eV}$, di mana ia adalah tepat dan bersamaan dengan kiraan teori pada jurang lapisan tenaga GaN untuk beroperasi pada suhu bilik.

KEYWORDS: GaN; bandgap energy; temperature; Bose-Einstein model;Varshni's model

\section{INTRODUCTION}

High temperature stability of the band-gap energy of semiconductor materials beyond room temperature is one of the most significant properties to be considered. It has been given the top-most priority in the field of semiconductor optoelectronic device design. Ensuring the stability of band-gap energy above room temperature is an engrossing issue to researchers. They are continuously looking for the best ideas to overcome this challenge, as it is one of the most important parameters to determine the electrical and optical properties of semiconductor materials. Since the transition to a direct band-gap energy in the monolayer form has important implications for photonics, optoelectronics, and sensing, this characteristic requires further investigation [1]. Previously, a lot of methods have been applied to investigate the temperature dependence of the band-gap energy of semiconductor materials. Those include: the two-oscillator model by Passler, Bose-Einstein model, and Varshni's model [2-5]. These models are widely applied to analyze the effect of temperature on the band-gap energy of semiconductor materials for applications in optoelectronic devices like lasers, solar cells, and so on. Furthermore Group-III nitride semiconductor materials have been identified as a group of materials having greater potential than other groups of existing semiconductor materials. Therefore, these materials are widely used to fabricate optoelectronic semiconductor devices in the range between visible short-wavelength to the ultraviolet region [6, 7]. Hence, a detailed numerical analysis on the temperature dependence from low to high temperature of bandgap energy of these materials is necessary for a promising design of such devices especially for high temperature applications.

Group III-V nitride alloys are under extensive investigation in the field of semiconductor device design. These materials are widely used in order to design high performance semiconductor optoelectronic devices with lower temperature sensitivity. Lower temperature sensitivity is the key point to ensure the stable operation of the device. Hence, due to its scientific and technological importance, Group III nitride semiconductor materials have received extensive attention from the scientific community in this era of new technology in the fabrication of semiconductor optoelectronic devices with high temperature stability [8]. Among the Group III nitrides, GaN alloy is the most important material, because it has a wider range of band-gap energy in the ultraviolet spectral range at room temperature than other Group III nitrides. Therefore, it is vital to recognize the effect of temperature on the properties of the band-gap energy of $\mathrm{GaN}$ in order to calculate the band alignment for designing optoelectronic devices [9]. Currently, GaN is used widely to fabricate optoelectronic devices operating above room temperature. So, in this paper, we are going to focus on a comparative analysis of the effect of temperature on the band-gap energy of GaN and its stability beyond room temperature using the well-known Bose-Einstein model and Varshni's model. 


\section{ENERGY BAND-GAP AND EFFECTIVE MASS}

The energy band-gap of semiconductor materials is determined effectively by the temperature dependence of electron-phonon interactions due to the following reasons: (i) the band-gap reveals the bond energy, (ii) a rise in atmospheric temperature changes the chemical bonding as electrons are promoted to conduction band (CB) from valence band (VB). Within the inherent temperature range, the direct effects of thermal band-to-band excitations are negligible. Conversely, lattice phonons have relatively lower energies. Furthermore, at normal temperature these lattice phonons are excited in huge quantities [10]. The temperature insensitive operation is therefore important not only for the stability of the semiconductor device operation but also for the chemical composition of the active layer material of the solid state optoelectronic device structure. Otherwise, the device characteristics governed by the material property will also be changed. The analysis of temperature dependence of band-gap energy of semiconductor materials is essential in order to fabricate the semiconductor device.

Group-III Nitrides have a narrow band gap due to the non-parabolic configuration of the lowest $\mathrm{CB}$ of the semiconductor materials. The non-parabolic dispersion phenomena at the lowest $\mathrm{CB}$ of the Group-III nitrides occurs because of the k-p interaction transversely through the narrow gap between the $\mathrm{CB}$ and $\mathrm{VBs}$, for narrow direct band-gap semiconductor materials like $\mathrm{GaN}$. The non-parabolic dispersion for the $\mathrm{CB}$ of $\mathrm{GaN}$ is calculated by Kane's k-p model. Neglecting the spin-orbit splitting, which is very much smaller than the band gap [11], the CB dispersion relationship is given by the following equation:

$$
E_{c}=E_{G}+\frac{\mathrm{h}^{2} \mathrm{k}^{2}}{2 \mathrm{~m}_{0}}+\frac{1}{2}\left(\sqrt{\mathrm{E}_{\mathrm{G}}^{2}+4 \mathrm{E}_{\mathrm{P}} \frac{\mathrm{h}^{2} \mathrm{k}^{2}}{2 \mathrm{~m}_{0}}}-E_{G}\right)
$$

Where, $E_{G}$ is the intrinsic band-gap energy of the semiconductor material and $E_{P}$ is an energy parameter related to the interaction momentum matrix element.

Electron effective mass can be calculated using the standard definition of the density of states, using the following formula:

$$
m^{*}(\mathrm{k})=\frac{h^{2} k}{\frac{d E_{c}(k)}{d k}}
$$

Now from Eqs. (1) and (2) the following relationship is obtained.

$$
m^{*}(\mathrm{k})=\frac{\mathrm{m}_{0} \sqrt{\mathrm{E}_{\mathrm{G}}^{2}+4 \mathrm{E}_{\mathrm{P}} \frac{\mathrm{h}^{2} \mathrm{k}^{2}}{2 \mathrm{~m}_{0}}}}{\mathrm{E}_{\mathrm{P}}+\sqrt{\mathrm{E}_{\mathrm{G}}^{2}+4 \mathrm{E}_{\mathrm{P}} \frac{\mathrm{h}^{2} \mathrm{k}^{2}}{2 \mathrm{~m}_{0}}}} .
$$

On the other hand, the free carrier effective mass on the Fermi surface is given by the following equation:

$$
m^{*}(\mathrm{k})=\frac{\mathrm{ne}^{2}}{\varepsilon_{0} \varepsilon_{\infty} \omega_{\mathrm{p}}^{2}}
$$

Where $n$ is the carrier concentration, $\omega_{\mathrm{p}}$ is the plasma frequency, and $\varepsilon_{\infty}=6.7$ is the optical dielectric constant.

\section{TEMPERATURE DEPENDENCE OF BANDGAP ENERGY}

Exact demonstration of temperature dependence of band-gap energy of a semiconductor material is one of the most vital problems in the field of semiconductor 
technology. At room temperature, a large scattering of the values of band-gap energies is also reported in the last decade [12]. In this research work, we are going to investigate the accuracy of Varshni's model over the Bose-Einstein model to analyze the temperature dependence of the band-gap energy of $\mathrm{GaN}$. GaN has been chosen as the material for the analysis as it is the most widely used Group-III nitride semiconductor material to design semiconductor optoelectronic devices. In order to do so, a comparative analysis of these two models has been considered in this research work. The comparative analysis has been done through a numerical approach.

\subsection{Varshni's Model}

The effect of temperature on the band-gap energy of semiconductor materials is analyzed using Varshni's formula. Varshni's formula is given in the following expression [4]:

$$
E_{g}(T)=E_{g}(0)-\frac{\gamma T^{2}}{T+\beta}
$$

Where $E_{g}(0)$ is the band-gap energy of the semiconductor material at $0 \mathrm{~K}, \mathrm{~T}$ is the temperature in Kelvin, and $\beta$ and $\gamma$ are Varshni's fitting parameters. The Varshni's fitting parameters of semiconductor materials have been investigated comprehensively to analyze the temperature dependence of the band-gap energy in other nitride semiconductor materials [6].

So, by taking the first derivative of $E_{g}(T)$ with respect to temperature, the following equation is obtained.

$$
\frac{d E_{g}(T)}{d T}=-\gamma \frac{T(T+2 \beta)}{(T+\beta)^{2}}
$$

Here the (-ve) sign indicates that the band-gap energy of the semiconductor material decreases with the rise in temperature or vice versa. Therefore, considering only the amplitude of the rate of change of band-gap energy of the semiconductor material with respect to temperature, the following equation is obtained.

$$
\left|\frac{d E_{g}(T)}{d T}\right|=\gamma \frac{T(T+2 \beta)}{(T+\beta)^{2}}
$$

\subsection{Bose-Einstein Model}

The effect of temperature on band-gap energy is determined using the well known Bose-Einstein model [3]:

$$
E_{g}(T)=E_{g}(0)-\frac{2 a_{B}}{T e^{\frac{\theta_{B}}{T}-1}} .
$$

Where $a_{B}$ represents the strength of the exciton-phonon interaction and $\theta_{B}$ is mean phonon energy.

Now, taking the first derivative on both sides of Eq. (8) with respect to temperature, the following equation is obtained.

$$
\frac{d E_{g}(T)}{d T}=-\frac{2 a_{B} e^{\frac{\theta_{B}}{T}}}{T^{2}\left(e^{\frac{\theta_{B}}{T}}-1\right)^{2}}
$$

Here the (-ve) sign indicates that the band-gap energy of the semiconductor decreases with the rise in temperature or vice versa. Therefore, considering only the amplitude of the 
rate of change of band-gap energy with respect to temperature, the following equation is obtained.

$$
\left|\frac{d E_{g}(T)}{d T}\right|=\frac{2 a_{B} e^{\frac{\theta_{B}}{T}}}{T^{2}\left(e^{\frac{\theta_{B}}{T}}-1\right)^{2}}
$$

\section{RESULTS AND DISCUSSION}

This section presents a detailed description of the numerical analysis of the effects of temperature on the band-gap energy of GaN using the Bose-Einstein Model and Varshni's Model. The outcomes of the numerical analysis are presented graphically in Fig. 1 and Fig. 2 respectively. Figure 1 has been plotted using Eq. (5) and Eq. (8) respectively. Figure 2 has been plotted using Eq. (7) and Eq. (10) respectively.

Table 1: Band gap and Varshni parameters and of GaN

\begin{tabular}{cc}
\hline Parameter & GaN \\
\hline $\mathrm{E}_{\mathrm{g}}(0)(\mathrm{eV})$ & 3.507 \\
$\gamma(\mathrm{meV} / \mathrm{K})$ & 0.909 \\
$\mathrm{~B}$ & 830 \\
$\mathrm{a}_{\mathrm{B}}$ & 111 \\
$\theta_{B}$ & $300 \mathrm{~K}$ \\
\hline
\end{tabular}

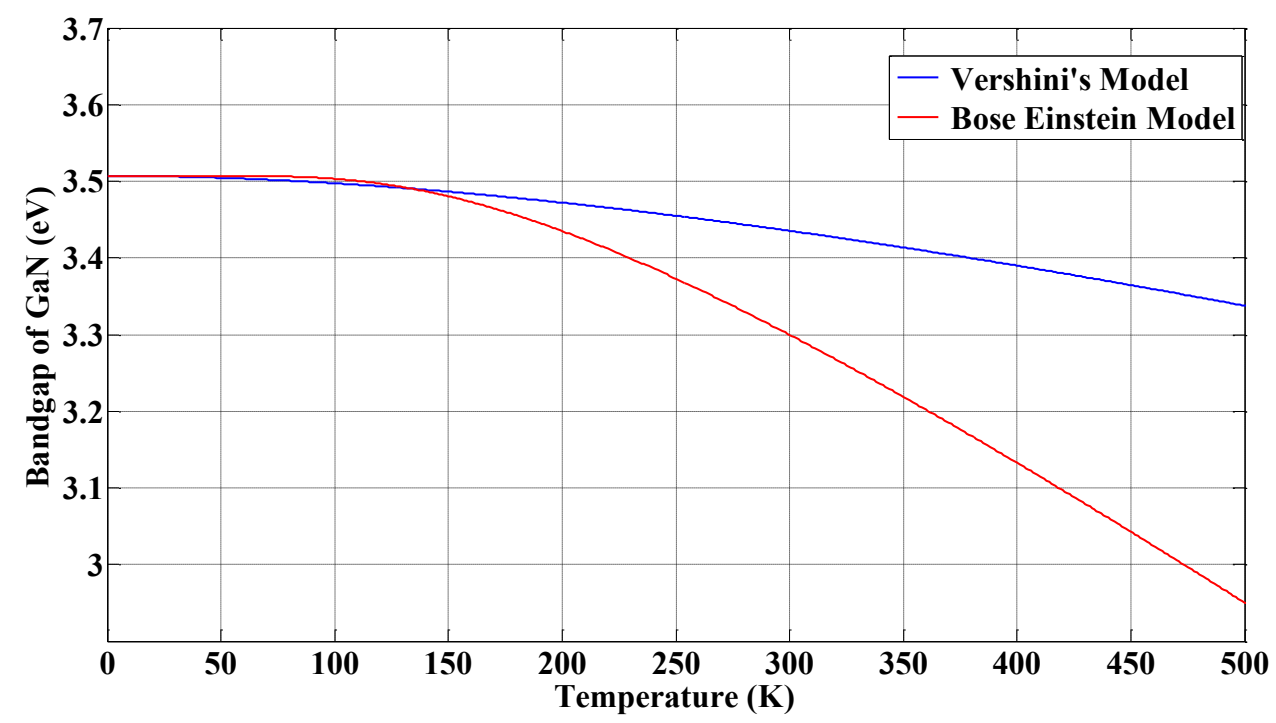

Fig. 1: Comparison of temperature dependency of band-gap energy of GaN using the Bose-Einstein model and Varshni's model.

As shown in Fig. 1, the best fit is obtained for Varshni's model and the Bose-Einstein model with the values of $\mathrm{E}_{\mathrm{g}}(0) \gamma$ and $\beta$ for $\mathrm{GaN}$, as in Table 1 . Figure 1 presents the temperature dependence of the band-gap energy of GaN. The red line and the blue line represent the temperature dependence of the band-gap energy of GaN using the wellknown Bose-Einstein model and Varshni's model respectively. The band-gap energy of $\mathrm{GaN}$ decreases non-uniformly with the uniform increase of temperature for both models used in our analysis. Curves shown in Fig. 1 give reliable values of the band-gap energy of 
$\mathrm{GaN}$. We are quite confident that the GaN band-gap has the weaker temperature dependence using the Bose-Einstein model than that of Varshni's model below $95^{\circ} \mathrm{K}$, but above $95 \mathrm{~K}$ Varshni's model shows that the change of band-gap energy with respect to temperature is small as compared to that of the Bose-Einstein model. So, from the above discussion, it is clear for devices operating at higher temperatures that Varshni's model should be applied. Another advantage of using the said model is the ease of calculation of the critical operating temperature.

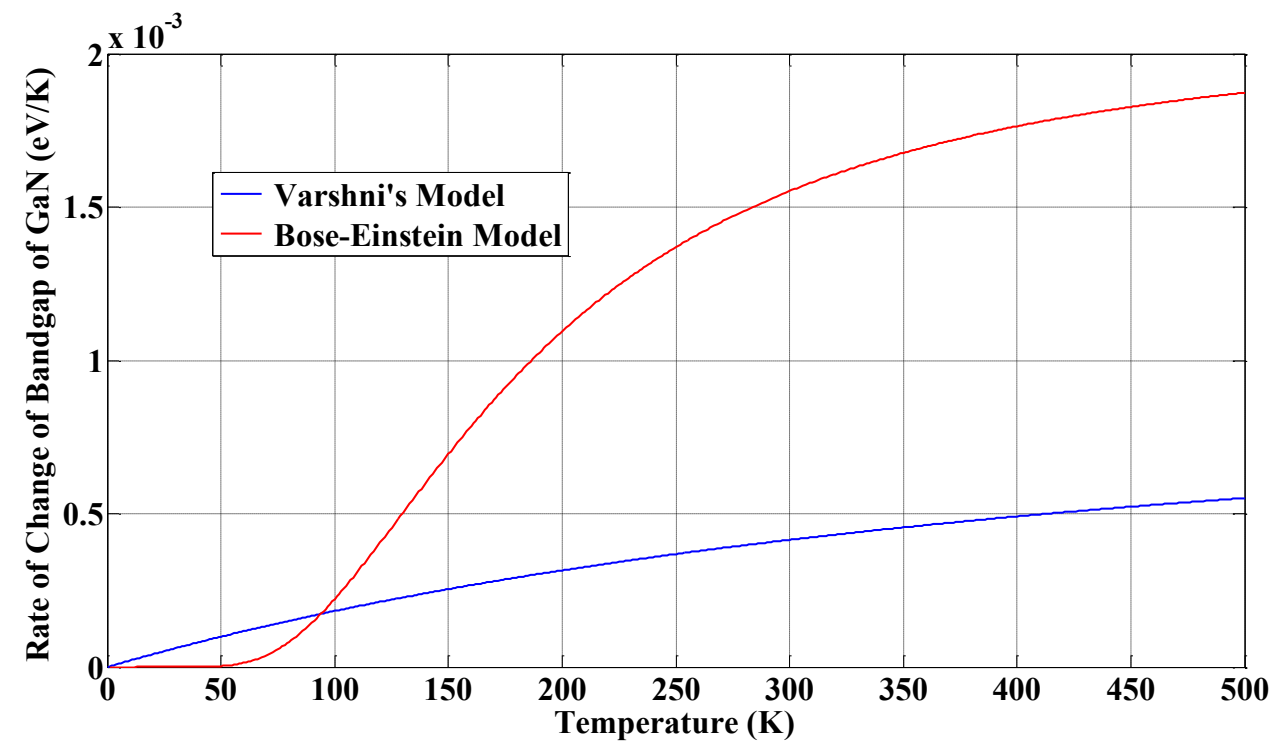

Fig. 2: Comparison of the rate of change of band-gap energy between the Bose-Einstein model and Varshni's model.

Figure 2 is plotted using Eq. (7) and Eq. (10). Fig. 2 presents the effect of temperature on the rate of change of the band-gap energy of GaN. The red line and the blue line represent the effect of temperature on the rate of change of the band-gap energy of GaN using the well-known Bose-Einstein model and Varshni's model respectively. The rate of change of the band-gap energy of $\mathrm{GaN}$ increased non-uniformly with the uniform increase of temperature for both models used in our analysis. It is revealed from Fig. 2 that at room temperature $(\mathrm{T}=300 \mathrm{~K})$, the rate of the change of the band-gap energy is only $0.3 \mathrm{meV} / \mathrm{K}$ using Varshni's model but the band-gap energy is about $2.4 \mathrm{meV} / \mathrm{K}$ using the BoseEinstein model. From Fig. 2, we can also conclude that the effect of the change of temperature on the band-gap energy of $\mathrm{GaN}$ is almost linear in the case of Varshni's model. However, non-linear characteristics of temperature dependence are obtained using the Bose-Einstein model, which is another limitation of this model with respect to Varshni's model. Here it is seen that the band-gap of GaN changes dramatically in the range of $50 \mathrm{~K}$ to $160 \mathrm{~K}$.

\section{CONCLUSION}

In conclusion, we have analyzed the temperature dependence of direct band-gap energy of GaN using the Bose-Einstein model and Varshni's model in the temperature range between $0 \mathrm{~K}$ and $500 \mathrm{~K}$. Results show that using Varshni's model, the band-gap energy at $300 \mathrm{~K}$ was found to be $3.43 \mathrm{eV}$ (Fig. 1) which shows a good agreement with the band-gap of $\mathrm{GaN}$ for operation at room temperature, as obtained by Tangi and his research group [13]. In addition, Fig. 1 shows the band-gap of $\mathrm{GaN}$ was found to be around $3.3 \mathrm{eV}$ 
using the Bose-Einstein model, which is far below the recognized value of the band-gap energy of $\mathrm{GaN}$. The temperature independence and large value of the broadening parameter might be related to the wide range of effective mass. Hence, the material property will be changed, which will also affect the device characteristics. We can conclude that the stability of the band-gap energy is essential to ensure the stability of the $\mathrm{CB}$ dispersion and the effective mass of the material. Finally, we can say that Varshni's model is more reliable than the Bose-Einstein model in the temperature range above $95 \mathrm{~K}$.

\section{ACKNOWLEDGEMENT}

The post-doctorate fellowship for the first author by the International Islamic University Malaysia is gratefully acknowledged.

\section{REFERENCES}

[1] Wang QH, Kalantar-Zadeh K, Kis A, Coleman JN, Strano MS. (2012) Electronics and optoelectronics of two-dimensional transition metal dichalcogenides. Nature Nanotechnology, 7(11):699-712.

[2] Passler R. (2001) Dispersion-related assessments of temperature dependences for the fundamental band gap of hexagonal GaN. J. Applied Physics, 90(8):3956-3964.

[3] Walukiewicz W, Li SX, Wu J, Yu KM, Ager JW, Haller EE, Lu H, Schaff WJ. (2004) Optical properties and electronic structure of InN and In-rich group III-nitride alloys. J. Crystal Growth, 269:119-127.

[4] Cui K, Fathololoumi S, Kibria MG, Botton GA, Mi Z. (2012) Molecular beam epitaxial growth and characterization of catalyst-free $\mathrm{InN} / \mathrm{InxGa1-xN}$ core/shell nanowire heterostructures on Si (111) substrates, Nanotechnology, 23(8):085205.

[5] Sarswat PK, Free ML. (2012) A study of energy band gap versus temperature for $\mathrm{Cu} 2 \mathrm{ZnSnS} 4$ thin films. Physica B: Condensed Matter, 407(1):108-111.

[6] Humayun MA, Rashid MA, Malek F, Hussain AN. (2012) Effect of lattice constant on bandgap energy and optimization and stabilization of high-temperature $\operatorname{In}_{\mathrm{x}} \mathrm{Ga}_{1-\mathrm{x}} \mathrm{N}$ quantum-dot lasers. J. Russian Laser Research,33(4):387-394.

[7] Rashid MA, Yusuf A, Humayun MA, Al-Khateeb AKNM, Tamaki S. (2013) Stability analysis of solar cell characteristics above room temperature using indium nitride based quantum dot. American J. Applied Sciences,10(11):1345-1350.

[8] Hossain MM, Humayun MA, Hasan MT, Bhuiyan AG, Hashimoto A, Yamamoto A. (2012) Proposal of high performance $1.55 \mu \mathrm{m}$ quantum dot heterostructure laser using InN. IEICE Transactions on Electronics, 95(2):255-261.

[9] Gupta L, Rath S, Abbi SC, Jain FC. (2003) Temperature dependence of the fundamental band gap parameters in cadmium-rich $\mathrm{Zn}_{\mathrm{x}} \mathrm{Cd}_{1-\mathrm{x}} \mathrm{Se}$ using photoluminescence spectroscopy. Pramana J. Physics, 61(4):729-737.

[10] O’Donnell KP, Chen X. (1991) Temperature dependence of semiconductor band gaps. Appl. Phys. Lett., 58(25):2924-2926.

[11] Wu J, Walukiewicz W. (2003) Band gaps of InN and group III nitride alloys. Super-lattices and Microstructures, 34:63-75.

[12] Manjon FJ, Hernandez-Fenollosa MA, Mari B, Li SF, Poweleit CD, Bell A, Menendez J, Cardona M. (2004) Effect of $\mathrm{N}$ isotopic mass on the photoluminescence and cathodoluminescence spectra of gallium nitride. The European Physical Journal B, 40:453458.

[13] Tangi M, Mishra P, Ng TK, Hedhili MN, Janjua B, Alias MS, Anjum DH, Tseng CC, Shi Y, Joyce HJ, Li LJ. (2016) Determination of band offsets at GaN/single-layer MoS2 heterojunction. Applied Physics Letters, 109(3):032104. 